Article

\title{
Influence of Titanium Dioxide Nanoparticles on the Sulfate Attack upon Ordinary Portland Cement and Slag-Blended Mortars
}

\author{
Atta-ur-Rehman, Abdul Qudoos, Hong Gi Kim and Jae-Suk Ryou * (iD \\ Department of Civil and Environmental Engineering, Hanyang University, 222, Wangsimni-ro, Seongdong-gu, \\ Seoul 04763, Korea; attabrcian@gmail.com (A.R.); qudoos.engnr@gmail.com (A.Q.); \\ dmkg1404@naver.com (H.G.K.) \\ * Correspondence: jsryou@hanyang.ac.kr; Tel.: +82-2-2220-4323
}

Received: 30 January 2018; Accepted: 27 February 2018; Published: 28 February 2018

\begin{abstract}
In this study, the effects of titanium dioxide $\left(\mathrm{TiO}_{2}\right)$ nanoparticles on the sulfate attack resistance of ordinary Portland cement (OPC) and slag-blended mortars were investigated. OPC and slag-blended mortars (OPC:Slag $=50: 50$ ) were made with water to binder ratio of 0.4 and a binder to sand ratio of $1: 3 . \mathrm{TiO}_{2}$ was added as an admixture as $0 \%, 3 \%, 6 \%, 9 \%$ and $12 \%$ of the binder weight. Mortar specimens were exposed to an accelerated sulfate attack environment. Expansion, changes in mass and surface microhardness were measured. Scanning Electron Microscopy (SEM), Energy Dispersive Spectroscopy (EDS), X-ray Diffraction (XRD), Thermogravimetry Analysis (TGA) and Differential Scanning Calorimetry (DSC) tests were conducted. The formation of ettringite and gypsum crystals after the sulfate attack were detected. Both these products had caused crystallization pressure in the microstructure of mortars and deteriorated the mortars. Our results show that the addition of nano- $\mathrm{TiO}_{2}$ accelerated expansion, variation in mass, loss of surface microhardness and widened cracks in OPC and slag-blended mortars. Nano- $\mathrm{TiO}_{2}$ containing slag-blended mortars were more resistant to sulfate attack than nano- $\mathrm{TiO}_{2}$ containing $\mathrm{OPC}$ mortars. Because nano- $\mathrm{TiO}_{2}$ reduced the size of coarse pores, so it increased crystallization pressure due to the formation of ettringite and gypsum thus led to more damage under sulfate attack.
\end{abstract}

Keywords: titanium dioxide; nanoparticles; photocatalysis; sulfate attack; mortar; cement; blast furnace slag; expansion; deterioration; microcracks

\section{Introduction}

\subsection{Background}

Titanium dioxide $\left(\mathrm{TiO}_{2}\right)$ is a white and inorganic material. It is used as an effective photocatalyst and can be activated by light radiation to degrade organic and inorganic pollutants present in the water and air through oxidation-reduction process. In recent decades, $\mathrm{TiO}_{2}$ has been added to concrete during mixing to yield a product with self-cleaning and air purifying properties [1]. $\mathrm{TiO}_{2}$ can clean the surface of concrete by degrading certain pollutants deposited on its surface in the presence of sunlight and can also convert harmful gases like nitrous oxides and volatile organic compounds (VOCs) to less harmful products [2,3]. Concrete with the addition of $\mathrm{TiO}_{2}$ has been referred to in the literature as self-cleaning, air purifying, or photocatalytic concrete. Photocatalytic concrete has been effectively used in the pavement blocks, tunnels, sidewalks and external walls of buildings for air purifying purposes and to maintain the aesthetic properties of buildings [4,5]. Additionally, ground granulated blast furnace slag (GGBFS) is an industrial byproduct with a white color. Use of slag in cementitious materials is environmentally beneficial as it helps in reducing carbon dioxide emissions 
and energy use due to cement production [6]. It can be used in concentrations up to $30 \%$ to replace white Portland cement for architectural effects in white concrete structures [7]. The aesthetic appeal of such structures can be preserved by adding nano- $\mathrm{TiO}_{2}[4,8]$. Simultaneous use of $\mathrm{TiO}_{2}$ and slag in cementitious materials can inherit them with beneficial characteristics of both slag and $\mathrm{TiO}_{2}$.

Sulfate attack is one of the most aggressive environmental conditions to address for concrete. Sulfate ions present in the soil, run-off water, seawater, groundwater and sewer lines can move to the interior of the concrete through pores and react with unhydrated and hydrated alumina phases, portlandite $(\mathrm{CH})$, calcium silicate hydrate $(\mathrm{CSH})$ to produce ettringite and gypsum. Incoming $\mathrm{SO}_{4}{ }^{2-}$ ions react with calcium alumino monosulfate phases and produce ettringite $\left(3 \mathrm{CaO} \cdot \mathrm{Al}_{2} \mathrm{O}_{3} \cdot 3 \mathrm{CaSO}_{4} \cdot 32 \mathrm{H}_{2} \mathrm{O}\right)$ according to Equation (1) [9]:

$$
\mathrm{SO}_{4}{ }^{2-}+4 \mathrm{CaO} \cdot \mathrm{Al}_{2} \mathrm{O}_{3} \cdot \mathrm{SO}_{3} \cdot 12 \mathrm{H}_{2} \mathrm{O}+2 \mathrm{Ca}^{2+}+20 \mathrm{H}_{2} \mathrm{O} \rightarrow 3 \mathrm{CaO} \cdot \mathrm{Al}_{2} \mathrm{O}_{3} \cdot 3 \mathrm{CaSO}_{4} \cdot 32 \mathrm{H}_{2} \mathrm{O}
$$

Sodium sulfate reacts with portlandite to produce gypsum and sodium hydroxide according to Equation (2):

$$
\mathrm{Na}_{2} \mathrm{SO}_{4}+\mathrm{Ca}(\mathrm{OH})_{2} \rightarrow \mathrm{CaSO}_{4} \cdot 2 \mathrm{H}_{2} \mathrm{O}+\mathrm{NaOH}
$$

Gypsum reacts with hydrated products such as calcium aluminates, calcium sulfoaluminate (monosulfate- $\mathrm{C}_{4} \mathrm{ASH}_{12-18}$ ) or tricalcium aluminate, (unhydrated phase in cement clinker) to produce ettringite, as given in the Equations (3)-(5):

$$
\begin{gathered}
4 \mathrm{CaO} \cdot \mathrm{Al}_{2} \mathrm{O}_{3} \cdot 13 \mathrm{H}_{2} \mathrm{O}+3\left(\mathrm{CaSO}_{4} \cdot 2 \mathrm{H}_{2} \mathrm{O}\right)+13 \mathrm{H}_{2} \mathrm{O} \rightarrow 3 \mathrm{CaO} \cdot \mathrm{Al}_{2} \mathrm{O}_{3} \cdot 3 \mathrm{CaSO}_{4} \cdot 32 \mathrm{H}_{2} \mathrm{O}+\mathrm{Ca}(\mathrm{OH})_{2} \\
4 \mathrm{CaO} \cdot \mathrm{Al}_{2} \mathrm{O}_{3} \cdot \mathrm{SO}_{3} \cdot 12 \mathrm{H}_{2} \mathrm{O}+2\left(\mathrm{CaSO}_{4} \cdot 2 \mathrm{H}_{2} \mathrm{O}\right)+(10-16) \mathrm{H}_{2} \mathrm{O} \rightarrow 3 \mathrm{CaO} \cdot \mathrm{Al}_{2} \mathrm{O}_{3} \cdot 3 \mathrm{CaSO}_{4} \cdot 32 \mathrm{H}_{2} \mathrm{O} \\
3 \mathrm{CaO} \cdot \mathrm{Al}_{2} \mathrm{O}_{3}+3\left(\mathrm{CaSO}_{4} \cdot 2 \mathrm{H}_{2} \mathrm{O}\right)+26 \mathrm{H}_{2} \mathrm{O} \rightarrow 3 \mathrm{CaO} \cdot \mathrm{Al}_{2} \mathrm{O}_{3} \cdot 3 \mathrm{CaSO}_{4} \cdot 32 \mathrm{H}_{2} \mathrm{O}
\end{gathered}
$$

Ettringite is an expansive product and causes expansion in the hardened cement paste. Expansion due to gypsum is disputed [10], researchers agree that gypsum softens mortar and reduces its strength [11]. If the expansive stresses from the formation of new products exceed the tensile strength of the hardened concrete, then microcracks are formed. These microcracks allow greater transport of sulfate ions from the external environment to the interior of the concrete and accelerate the sulfate attack. Sulfate attack increases porosity, reduces strength, softens concrete, changes mass, causes expansion, cracking and spalling. The severity and nature of these defects are dependent on factors such as cement type and composition, water/binder ratio, presence and amount of supplementary cementitious materials, porosity, permeability, ambient temperature, the concentration of sulfate ions and types of cations, such as sodium or magnesium. More details relating to the mechanism of sulfate attack can be found in the previous reviews [9,11-13].

\subsection{Research Significance}

During service life, photocatalytic concrete is in contact with soil or water; as both soil and water are sources of sulfate attack, there is a high possibility of such an attack. The addition of nano- $\mathrm{TiO}_{2}$ alters the mechanical properties and the microstructure of the concrete [14]; therefore, it is necessary to investigate sulfate attack on nano- $\mathrm{TiO}_{2}$ containing concrete to design efficient photocatalytic structures and avoid premature failure. Research into sulfate attack on photocatalytic mortars is sparse. In this study, we investigate the effects of nano- $\mathrm{TiO}_{2}$ on the sulfate attack resistance of pure Portland cement mortars and slag-blended mortars at two exposure temperatures. $\mathrm{Nano}_{-} \mathrm{TiO}_{2}$ was added to the mortars at binder weight percentages of $0 \%, 3 \%, 6 \%, 9 \%$ and $12 \%$. Other researchers have also used large $\mathrm{TiO}_{2}$ dosage in their studies [14-18]. Lower dosage of $\mathrm{TiO}_{2}$ in the cementitious materials may be insufficient to ensure self-cleaning and air purification at longer ages. Therefore, higher dosage of $\mathrm{TiO}_{2}$ was chosen. The mortars were immersed in $10 \%$ sodium sulfate solution at 5 and $25{ }^{\circ} \mathrm{C}$ and expansion, changes in 
mass and loss of surface microhardness were measured. SEM, EDS, XRD, TGA and DSC tests were conducted on deteriorated specimens.

\section{Experimental Program}

\subsection{Materials and Mix Proportion}

Titanium dioxide used in this study was produced by Cristal France SAS (Thann, France). According to Cristal Corporate, the content of anatase phase in the product was more than $99 \%$, the size of nanoparticles ranged from $10 \sim 60 \mathrm{~nm}$ and specific surface area of the powder was $85.6 \mathrm{~m}^{2} / \mathrm{g}$. Ordinary Portland cement and ground granulated blast furnace slag were purchased from a local company (Dongyong Cement, Co., Ltd., Seoul, Korea). The chemical compositions of the cement and slag are given in Table 1.

Table 1. Chemical composition and physical properties of ordinary Portland cement (OPC) and ground granulated blast furnace slag (GGBFS).

\begin{tabular}{ccc}
\hline Oxide & OPC & GGBFS \\
\hline $\mathrm{CaO}(\%)$ & 62.27 & 40.72 \\
$\mathrm{SiO}_{2}(\%)$ & 21.32 & 34.86 \\
$\mathrm{Al}_{2} \mathrm{O}_{3}(\%)$ & 5.19 & 12.54 \\
$\mathrm{SO}_{3}(\%)$ & 2.17 & 1.32 \\
$\mathrm{MgO}(\%)$ & 3.04 & 7.61 \\
$\mathrm{Fe}_{2} \mathrm{O}_{3}(\%)$ & 2.23 & 0.72 \\
$\mathrm{~K}_{2} \mathrm{O}(\%)$ & 0.58 & 0.67 \\
$\mathrm{Na}_{2} \mathrm{O}(\%)$ & 0.52 & 0.38 \\
Loss on ignition & 1.5 & 0.43 \\
Blaine fineness (cm $\left.{ }^{2} / \mathrm{g}\right)$ & 3400 & 4600 \\
Specific Gravity & 3.15 & 2.9 \\
\hline
\end{tabular}

Control and binder $/ \mathrm{TiO}_{2}$ composite mortars were made by adding $\mathrm{TiO}_{2}$ as 3\%, 6\%, 9\% and $12 \%$ of the binder weight. Water/binder ratio was fixed to 0.4 , a polycarboxylate ether-based water reducing admixture ( $0-1.2 \%$ of the binder weight) was added to adjust the fluidity of the mortars. Mix proportions are shown in Table 2 . The $\mathrm{TiO}_{2}$ particles were first deagglomerated and dispersed in water through ultrasonication using a sonic probe for at least $45 \mathrm{~min}$. Then water reducing admixture was added in the water and stirred for one more minute. This mixture was slowly added to the sand and binder in the mortar mixer and then mortar specimens were formed.

Table 2. Mix proportion.

\begin{tabular}{ccccccc}
\hline Acronym & OPC $(\mathbf{g})$ & Slag $\mathbf{( g )}$ & $\mathbf{T i O}_{\mathbf{2}} \mathbf{( g )}$ & Sand (g) & $\begin{array}{c}\text { Water/Binder } \\
\text { Ratio }\end{array}$ & $\begin{array}{c}\text { Water Reducing } \\
\text { Admixture } \mathbf{( \% )}\end{array}$ \\
\hline 0\% OPC & 1500 & 0 & 0 & 4500 & 0.40 & 0 \\
3\% OPC & 1500 & 0 & 45 & 4500 & 0.40 & 0.25 \\
6\% OPC & 1500 & 0 & 90 & 4500 & 0.40 & 0.6 \\
9\% OPC & 1500 & 0 & 135 & 4500 & 0.40 & 1 \\
12\% OPC & 1500 & 0 & 180 & 4500 & 0.40 & 1.2 \\
0\% slag-blended & 750 & 750 & 0 & 4500 & 0.40 & 0 \\
3\% slag-blended & 750 & 750 & 45 & 4500 & 0.40 & 0.2 \\
6\% slag-blended & 750 & 750 & 90 & 4500 & 0.40 & 0.55 \\
9\% slag-blended & 750 & 750 & 135 & 4500 & 0.40 & 1 \\
12\% slag-blended & 750 & 750 & 180 & 4500 & 0.40 & 1.2 \\
\hline
\end{tabular}

\subsection{Test Procedure and Specimen Preparation}

ASTM C 1012 [19] is one of the test methods used to evaluate sulfate resistance. According to this method, mortar prisms with dimensions of $25.4 \mathrm{~mm} \times 25.4 \mathrm{~mm} \times 279.4 \mathrm{~mm}$ with pins at both ends are prepared and stored in limewater until reaching a strength of $20 \mathrm{MPa}$. They are then stored 
in $5 \%$ sodium sulfate $\left(\mathrm{Na}_{2} \mathrm{SO}_{4}\right)$ solution and any expansion is measured. The ASTM C 1012 process takes several months to a year to complete; many accelerated tests have been proposed using small specimen sizes and higher concentrations of sulfate solution. A summary of these tests can be found in the work of Kim Van Tittelboom et al. [20]. Ferraris et al. [21] developed a new accelerated test technique for measuring the sulfate resistance of mortar. Here, authors used their test method with some modifications. They had immersed $10 \mathrm{~mm} \times 10 \mathrm{~mm} \times 40 \mathrm{~mm}$ rectangular prism specimens in $5 \% \mathrm{Na}_{2} \mathrm{SO}_{4}$ solution. In this study, cylindrical mortar specimens with a diameter of $10 \mathrm{~mm}$ and length $40 \mathrm{~mm}$ were immersed in $10 \% \mathrm{Na}_{2} \mathrm{SO}_{4}$ solution. Because expansion depends on size rather than shape, specimen size is a crucial factor in evaluating sulfate resistance [20,22], although crack patterns might differ in cylindrical and rectangular prisms. To cast the specimens, molds were made in the laboratory using the barrel of syringes with an internal diameter of $10 \mathrm{~mm}$. The barrel of a syringe was cut from the plunger and needle side to a length of $40 \mathrm{~mm}$ and was then fixed on a glass plate with epoxy, as shown in Figure 1a. The mortar was cast in molds in four layers and each layer was compacted 20 times with a $2 \mathrm{~mm}$ steel rod and the surface was leveled. Twenty specimens were made for each mix proportion, for a total of 200 specimens. Mortar cubes and prisms were casted to measure compressive and flexural strengths After $48 \mathrm{~h}$ of casting, the mortar specimens were removed from the molds and placed in saturated limewater for 28 days. Four specimens of each mix proportion were left immersed in saturated limewater while other specimens were selected for immersion in $\mathrm{Na}_{2} \mathrm{SO}_{4}$ solution. The studs were firmly fixed on the ends of these mortar specimens with epoxy. To allow sulfate ions to attack only from the sides, the epoxy was applied to both end faces of the specimens. Then they were immersed in $10 \% \mathrm{Na}_{2} \mathrm{SO}_{4}$ solution as shown in Figure $1 \mathrm{~b}$, which was renewed every other week. The volumetric ratio of the solution to the test specimens was 20:1. Half of the specimens were stored at a temperature of $5 \pm 1{ }^{\circ} \mathrm{C}$ and a half at $25 \pm 1{ }^{\circ} \mathrm{C}$. Both temperatures were maintained constant for the entirety of the study period. Compressive and flexural strength tests were conducted according to ASTM C109 [23] standard and ASTM C348 [24], respectively, at the age of 28 days. Water absorption was measured at the age of 28 days [25].

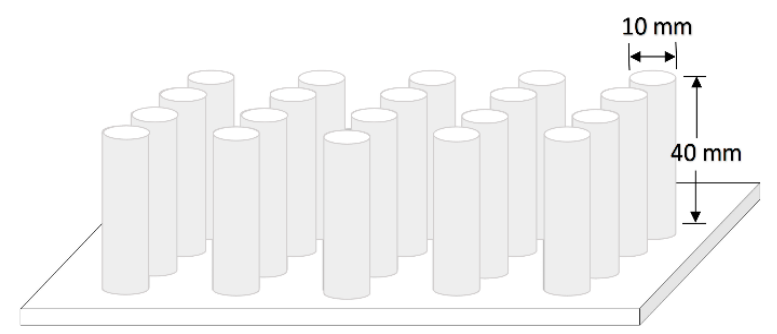

(a)

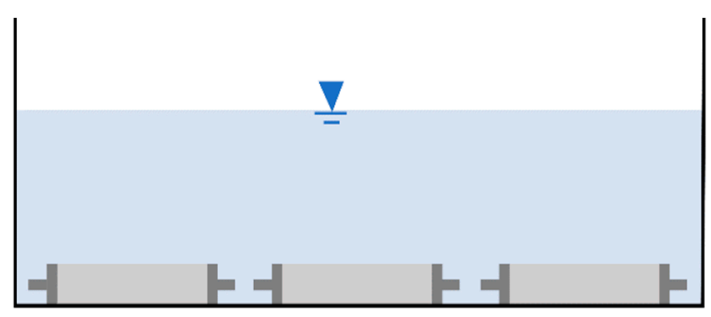

(b)

Figure 1. (a) A schematic diagram of molds prepared in the laboratory for casting cylindrical mortar specimens; (b) Mortar specimens immersed in $\mathrm{Na}_{2} \mathrm{SO}_{4}$ solution.

\subsection{Expansion and Mass Variation}

The length and mass of the specimens were measured every seventh day during the immersion period using Equations (6) and (7):

$$
\begin{aligned}
& \text { Increase in length at }(\mathrm{t})=\left(\mathrm{L}_{\mathrm{t}}-\mathrm{L}_{\mathrm{i}}\right) / \mathrm{L}_{\mathrm{i}} \times 100 \\
& \text { Increase in mass at }(\mathrm{t})=\left(\mathrm{M}_{\mathrm{t}}-\mathrm{M}_{\mathrm{i}}\right) / \mathrm{M}_{\mathrm{i}} \times 100
\end{aligned}
$$

where $\mathrm{L}$ is the length, $\mathrm{t}$ is the time, $\mathrm{i}$ is the initial and $\mathrm{M}$ is the mass. The test was stopped after 84 days of immersion. 


\subsection{Vickers Microhardness}

The Vickers microhardness test is a common surface hardness characterization technique [26]. In this method, a static load is applied for a fixed time on the surface of the material using an indenter and the area of indentation is calculated. The Vickers hardness indenter resembles a diamond pyramid in shape. The Vickers hardness value is the ratio of applied load to indentation contact area and is calculated according to Equation (8):

$$
\mathrm{HV}=2 \mathrm{P} \sin (\phi 2) / \mathrm{D}^{2}=1.854 \mathrm{P} / \mathrm{D}^{2}
$$

where $\mathrm{HV}$ is the Vickers hardness value, $\mathrm{P}$ is the load (kgf), $\mathrm{D}$ is the mean diagonal of the indentation pyramid $(\mathrm{mm})$ and $\phi=136^{\circ}$. To measure the Vickers microhardness, samples with a diameter of $10 \mathrm{~mm}$ and depth of $10 \mathrm{~mm}$ were obtained by cutting cylindrical specimens with a diamond saw cutter as shown in Figure 2a. Both ends of the obtained samples were successively polished with 400, 800, 1200 and 1500 grit polishing papers and placed in an oven at $55^{\circ} \mathrm{C}$ for $24 \mathrm{~h}$ to remove the humidity. A load of $0.1 \mathrm{kgf}$ was applied and maintained for $10 \mathrm{~s}$. Microhardness values were measured at 1, 2, 3, 4 and $5 \mathrm{~mm}$ from the external surface, as shown in Figure $2 \mathrm{~b}$. A minimum of 8 readings were taken at each depth. The test was conducted using a Vickers hardness tester THV-1MD (Capital Instrument, Beijing, China).

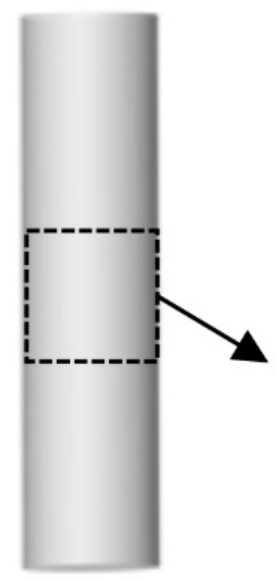

(a)

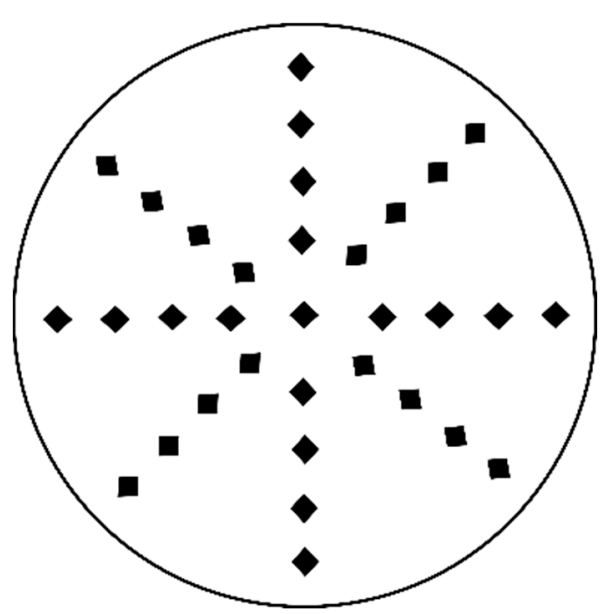

(b)

Figure 2. (a) The preparation of the sample used for microhardness; (b) Cross-sectional schematics of the sample used in the Vickers microhardness test.

\subsection{Microscopic Observation and Damage Rating}

Cracks were observed with a microscope, EGVM-452 M (EG Tech, Seoul, Korea). The samples were observed every four weeks both with the unaided eye and through the microscope to quantify the damage. The specimens were rated on a scale from 0 to 7 , as given in Table 3.

\subsection{XRD, SEM, EDS, TGA and DSC Analyses}

The damaged specimens were analyzed using X-ray diffraction (XRD, Rigaku, Tokyo, Japan), Scanning Electron Microscopy (SEM; Model S-3000 N, Hitachi, Tokyo, Japan) equipped with Energy Dispersive Spectroscopy (EDS) tester after 84 days of immersion. For XRD analysis, controlled and deteriorated mortar samples were ground, passed through a $200-\mu \mathrm{m}$ sieve. The XRD test was conducted using the RINT D/max $2500 \mathrm{X}$-ray diffractometer at a voltage of $40 \mathrm{kV}$, current of $30 \mathrm{~mA}$ and a scanning speed of $2^{\circ} / \mathrm{min}$ using $\mathrm{CuK} \alpha$ X-rays with a wavelength of $1.54 \AA$. For SEM and EDX analyses, samples were prepared according to Sarkar et al.'s work [27]. TGA and DSC analysis 
were conducted on the powdered samples obtained from sliced samples as shown in Figure 2a. The instrument used was Thermogravimetric Analyzer and Differential Scanning Calorimeter, DSC SDT Q600 (TA Instruments, New Castle, DE, USA). Samples were heated from room temperature to $1000{ }^{\circ} \mathrm{C}$ at the rate of $10{ }^{\circ} \mathrm{C} / \mathrm{min}$, nitrogen was purged at a flow rate of $100 \mathrm{~mL} / \mathrm{min}$. Powdered samples were prepared according to Lothenbach et al.'s work [28].

\section{Results and Discussion}

\subsection{Compressive, Flexural Strengths and Water Absorption}

Figure 3 shows the variation of compressive and flexural strengths with the addition of nano- $-\mathrm{TiO}_{2}$ in OPC and slag-blended mortars. Adding more than $6 \%$ nan- $-\mathrm{TiO}_{2}$ as weight of the binder led to a reduction in compressive strength of mortars while adding more than $3 \%$ nan- $\mathrm{TiO}_{2}$ as weight of the binder led to a reduction in flexural strength of mortars. Increase in compressive strength was due to filler effect of nano- $\mathrm{TiO}_{2}$ [29]. The water absorption results are shown in Figure 4 which shows that water absorption is reduced with the addition of nano- $\mathrm{TiO}_{2}$ in both type of mortars. This positive effect can be ascribed to the nano-TiO ${ }_{2}$ particles, which acted as fillers, served as nucleation sites for the hydration reaction, hydration products precipitated around them and disconnected pores in the paste. The reduction in water absorption due to slag addition can be ascribed to the their later hydration and formation of secondary CSH in capillary pores [30].

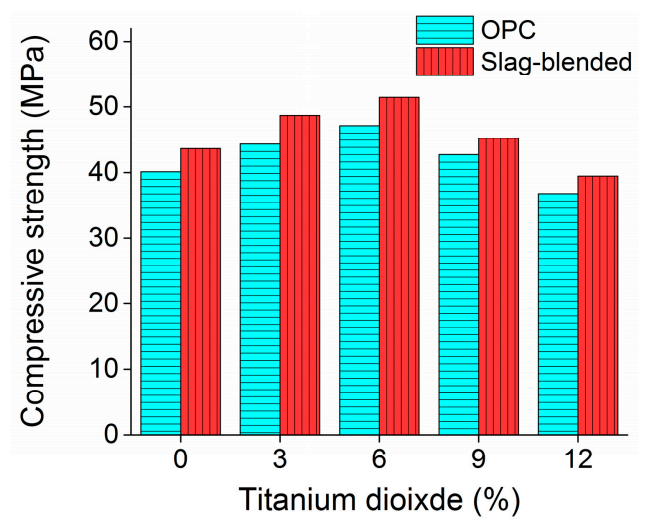

(a)

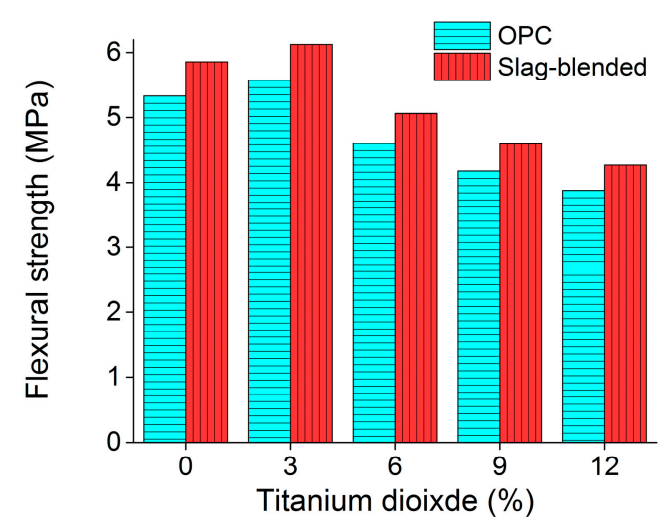

(b)

Figure 3. Variation of mechanical properties with the addition of nano- $\mathrm{TiO}_{2}$ in mortars at the age of 28 days (a) compressive strength (b) flexural strength.

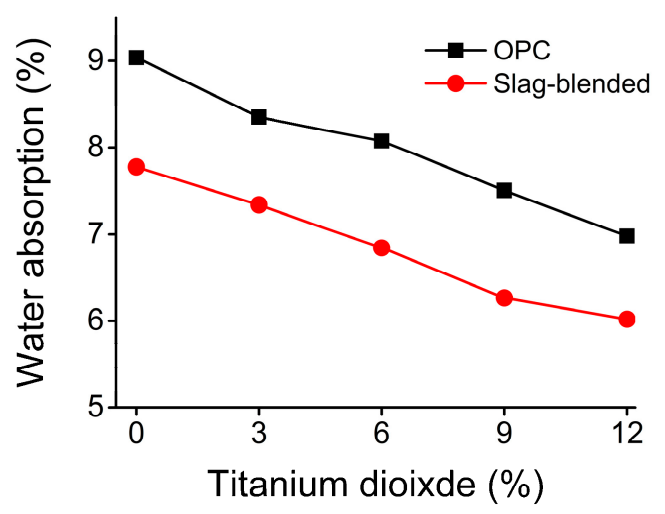

Figure 4. Variation of water absorption with the addition of nan- $\mathrm{TiO}_{2}$ in the mortars. 


\subsection{Expansion and Mass Variation}

Figures 5 and 6 show the expansion in nano- $\mathrm{TiO}_{2}$ containing OPC and slag-blended mortars immersed in $\mathrm{Na}_{2} \mathrm{SO}_{4}$ solution at $25^{\circ} \mathrm{C}$ and $5{ }^{\circ} \mathrm{C}$ for 84 days, respectively. The results show an increase in expansion rate with the addition of nano- $\mathrm{TiO}_{2}$. At $25{ }^{\circ} \mathrm{C}$, the expansion in $0 \%$ OPC mortars was $0.30 \%$, while the expansion in $3 \%, 6 \%$ and $9 \%$ OPC mortars was $0.36 \%, 0.43 \%$ and $0.54 \%$, respectively, after 84 days. The increase in expansion with the increase of nano- $\mathrm{TiO}_{2}$ occurred at both temperatures $\left(25\right.$ and $\left.5{ }^{\circ} \mathrm{C}\right)$. The comparison of expansion in OPC and slag-blended mortars showed that nano- $\mathrm{TiO}_{2}$ containing OPC mortars expanded more than nano- $\mathrm{TiO}_{2}$ slag-blended mortars. The expansion pattern differed between nano- $\mathrm{TiO}_{2}$ slag-blended and nano- $\mathrm{TiO}_{2}$ containing $\mathrm{OPC}$ mortars; whereas former exhibited a uniform rate of expansion but OPC mortars showed slow expansion initially and faster expansion at later times. Slag improves performance by acting as a physical filler and pozzolanic material [31]. Therefore nano- $\mathrm{TiO}_{2}$ containing slag mortars were more resistant to expansion. Storage temperature also showed a prominent effect on the rate of expansion of $\mathrm{TiO}_{2}$ containing mortars.

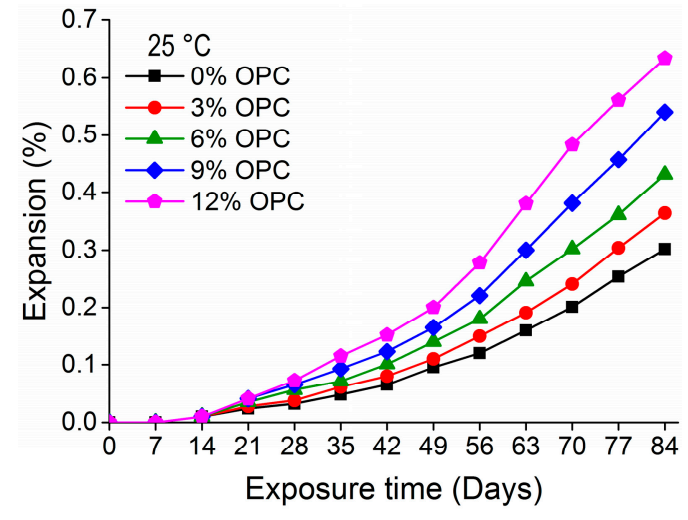

(a)

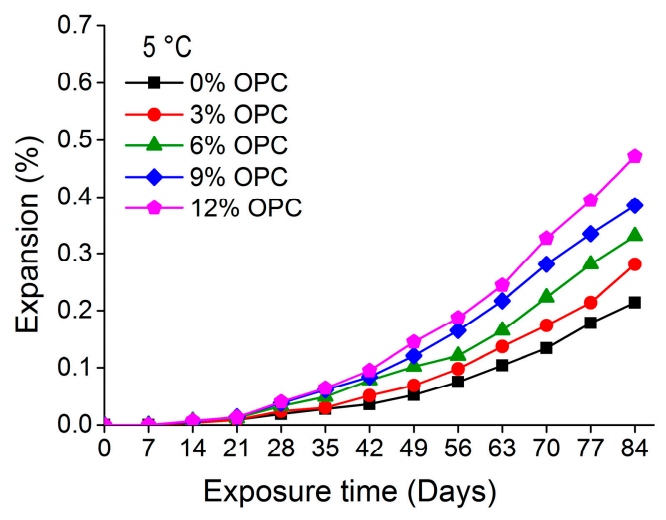

(b)

Figure 5. Expansion in nano- $\mathrm{TiO}_{2}$ containing $\mathrm{OPC}$ mortars immersed in $10 \% \mathrm{Na}_{2} \mathrm{SO}_{4}$ solution at (a) $25{ }^{\circ} \mathrm{C}$ (b) $5{ }^{\circ} \mathrm{C}$.

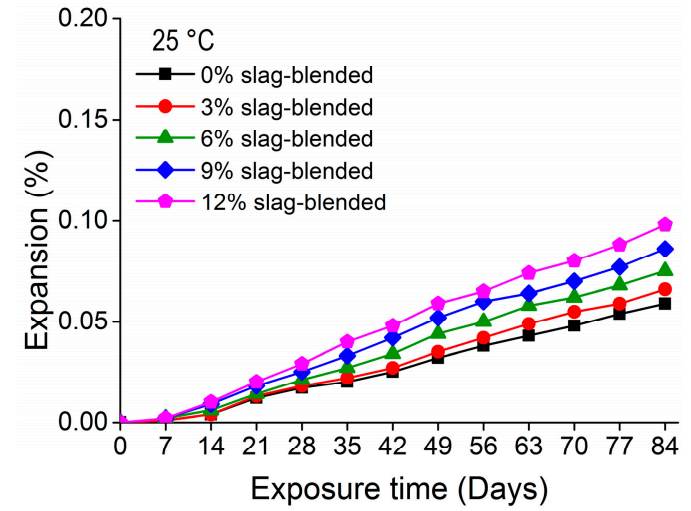

(a)

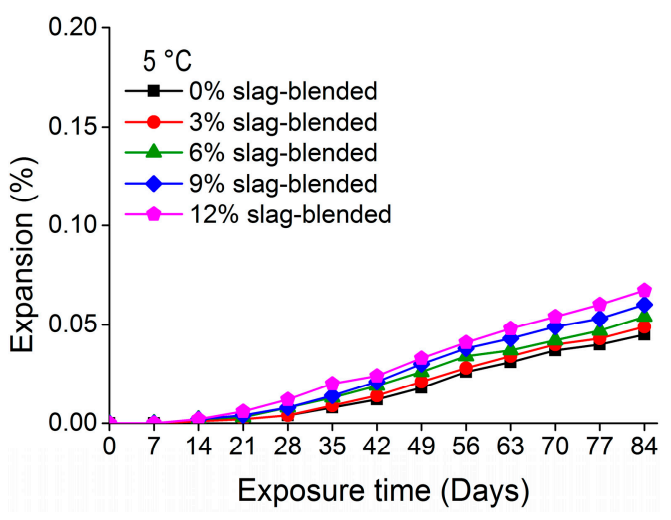

(b)

Figure 6. Expansion in nano- $\mathrm{TiO}_{2}$ containing slag-blended mortars immersed in $10 \% \mathrm{Na}_{2} \mathrm{SO}_{4}$ solution at (a) $25^{\circ} \mathrm{C}$ (b) $5{ }^{\circ} \mathrm{C}$.

Figures 7 and 8 show the mass variation for nano- $\mathrm{TiO}_{2}$ containing $\mathrm{OPC}$ and slag-blended mortars immersed in $\mathrm{Na}_{2} \mathrm{SO}_{4}$ solution at 25 and $5{ }^{\circ} \mathrm{C}$, respectively. The addition of $\mathrm{TiO}_{2}$ in mortars resulted in an additional mass gain. After immersion for 84 days at $25{ }^{\circ} \mathrm{C}, 12 \%$ OPC and $12 \%$ slag-blended mortars gained $3.01 \%$ and $1.41 \%$ mass, respectively, while $0 \%$ OPC and $0 \%$ slag-blended mortars gained $2.19 \%$ and $1.06 \%$ mass, respectively. The increase in mass of mortars may be due to absorption 
of sodium sulfate solution and precipitation of gypsum and ettringite in pores and cracks. The effects of $\mathrm{TiO}_{2}$ addition on the rate of mass increase were negligible in first few weeks but prominent at later stages. The increase in mass was higher in mortars immersed in sulfate solution at higher temperatures. The addition of slag refined pores and reduced capillary pores and their connectivity [6,32,33], hence reducing the absorption of sodium sulfate solution. Therefore, nano- $\mathrm{TiO}_{2}$ containing slag-blended mortars were less vulnerable to the formation of gypsum and ettringite and exhibited less expansion and variation in mass.

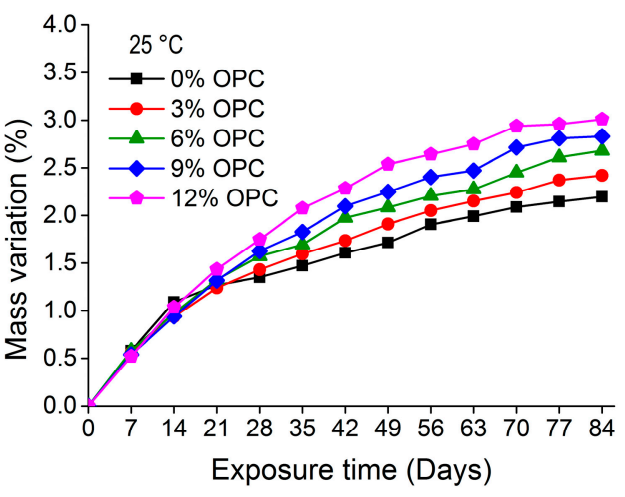

(a)

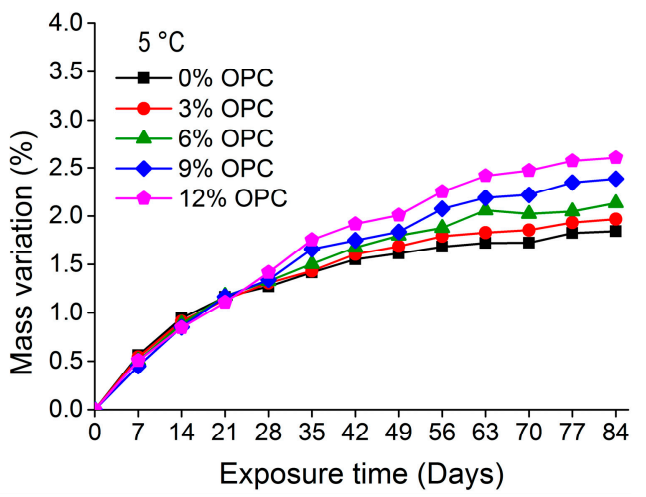

(b)

Figure 7. Mass variation in nano- $\mathrm{TiO}_{2}$ containing $\mathrm{OPC}$ mortars immersed in $10 \% \mathrm{Na}_{2} \mathrm{SO}_{4}$ solution at (a) $25^{\circ}$; (b) $5^{\circ} \mathrm{C}$.

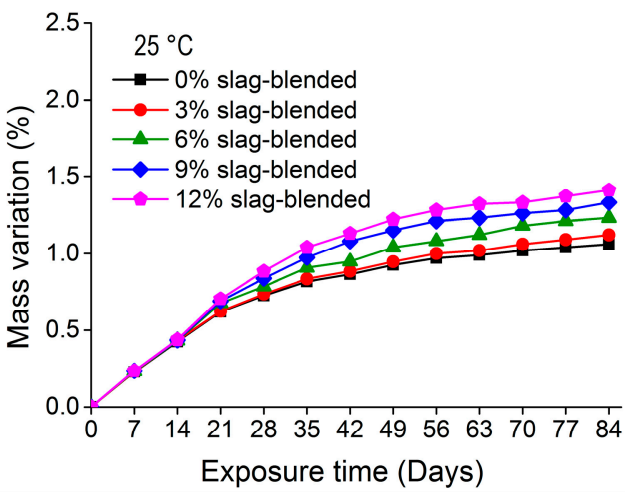

(a)

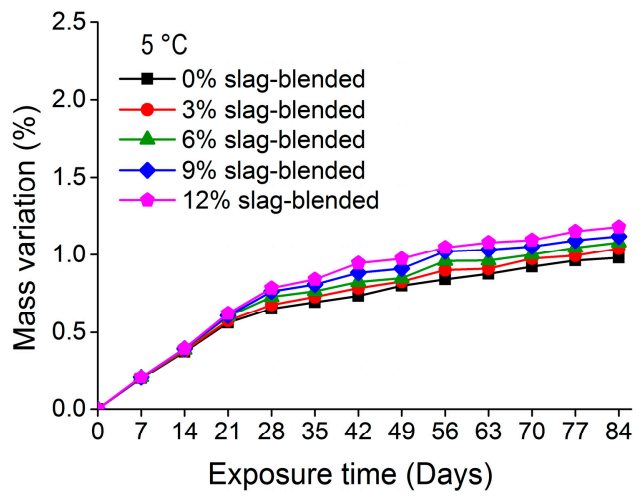

(b)

Figure 8. Mass variation in nano- $\mathrm{TiO}_{2}$ containing slag-blended mortars immersed in $10 \% \mathrm{Na}_{2} \mathrm{SO}_{4}$ solution at (a) $25^{\circ} \mathrm{C}$; (b) $5^{\circ} \mathrm{C}$.

\subsection{Microhardness}

The variation in Vickers hardness in OPC and slag-blended mortars immersed in $10 \% \mathrm{Na}_{2} \mathrm{SO}_{4}$ solution at $25^{\circ} \mathrm{C}$ is shown in Figure 9. It shows a greater loss of surface hardness with the addition of nano- $\mathrm{TiO}_{2}$. This figure also shows that sulfate attack caused a greater loss of surface hardness in nano- $\mathrm{TiO}_{2}$ containing OPC mortars than in nano- $\mathrm{TiO}_{2}$ containing slag-blended mortars. In OPC mortars, most of the depth is affected and the peripheral area was softened with respect to the inner depth, while in slag-blended mortars, the loss of surface hardness value extended up to $3 \mathrm{~mm}$ depth. This indicates the resistance of nano- $\mathrm{TiO}_{2}$ containing slag-blended mortars to sulfate attack and an increase in sulfate damage due to the addition of nanoparticles. 


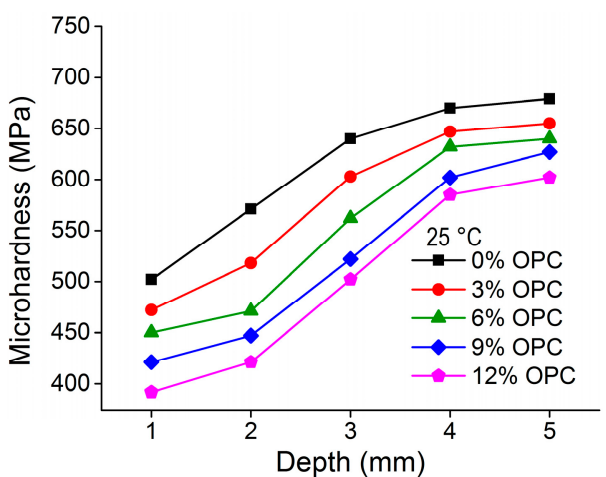

(a)

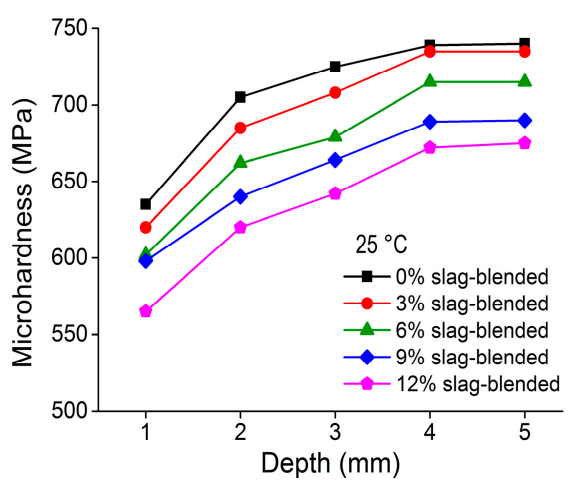

(b)

Figure 9. Variation in microhardness along depth in (a) nano- $\mathrm{TiO}_{2}$ containing $\mathrm{OPC}$ mortars and (b) nano- $\mathrm{TiO}_{2}$ containing slag-blended mortars immersed in $10 \% \mathrm{Na}_{2} \mathrm{SO}_{4}$ solution at $25{ }^{\circ} \mathrm{C}$.

\subsection{Microcracks}

Various cracks were formed on the surface of the specimens with respect to the axis of specimens, including perpendicular, diagonal and parallel. These cracks were referred to as transverse, diagonal and longitudinal, respectively. Cracks that changed direction from transverse to diagonal or longitudinal were identified as random cracks. Map cracks, which run in different directions and form hexagonal and irregular patterns on the surface of mortar, were also formed. At some points, spalling had occurred in the form of pop-outs and conical depressions due to the surrounding of an aggregate, or layer of the mortar, by a map crack. A representative view of the surface cracks formed on the specimens is shown in Figures 10 and 11, all of which occurred as a result of sulfate attack. Due to sulfate attack, transverse and diagonal cracks were numerous and wider than other types of cracks, followed in severity by map cracks and longitudinal cracks. This suggests that expansion of mortar samples is the dominant damage caused by sulfate attack. Table 3 shows the damage rating of nano- $\mathrm{TiO}_{2}$ containing mortars on a scale from 0 to 7 . The details of scale can be seen in the footnote of table. Severity of cracks varied among mix proportions. For example, 12\% and 9\% OPC mortars were severly damaged after 84 days compared to 3\% and $0 \%$ OPC mortars. The same pattern was found in slag-blended mortars.
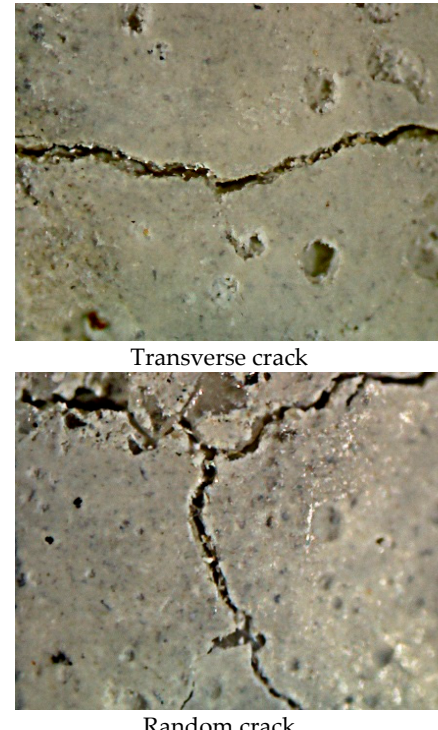

Random crack

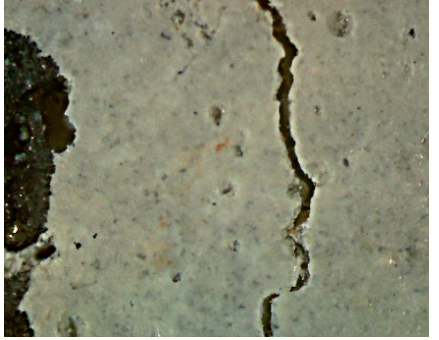

Longitudinal crack

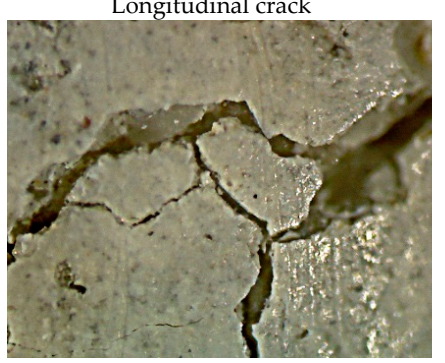

Map cracks and spalling

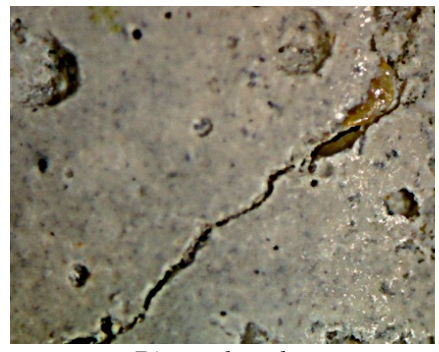

Diagonal crack

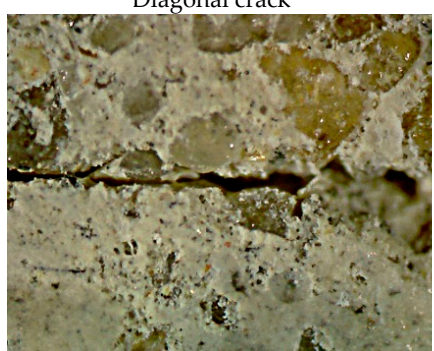

Surface scaling and transverse crack

Figure 10. A representative view of cracks formed on the surface of $12 \%$ OPC mortars observed under a light microscope after 84 days of immersion in $\mathrm{Na}_{2} \mathrm{SO}_{4}$ solution at $25^{\circ} \mathrm{C}$. 


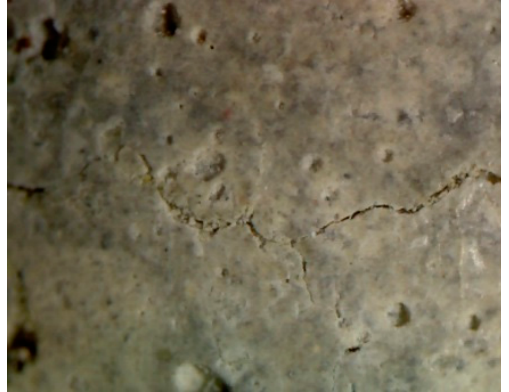

Transverse crack

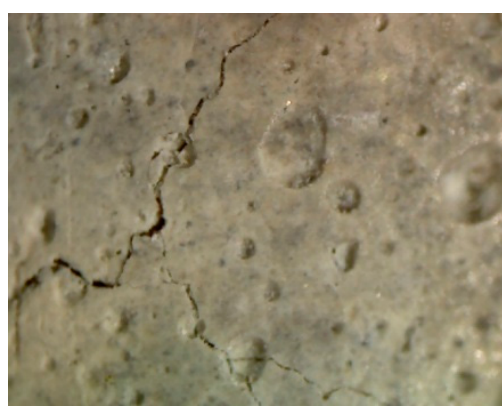

Random crack

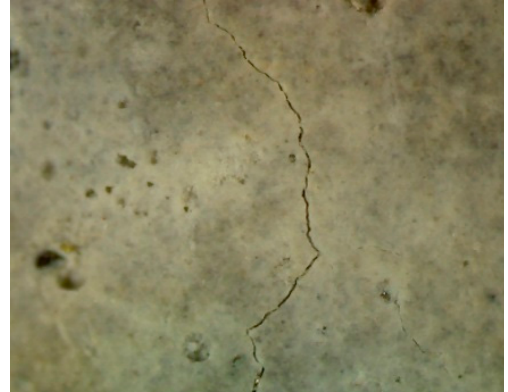

Longitudinal crack

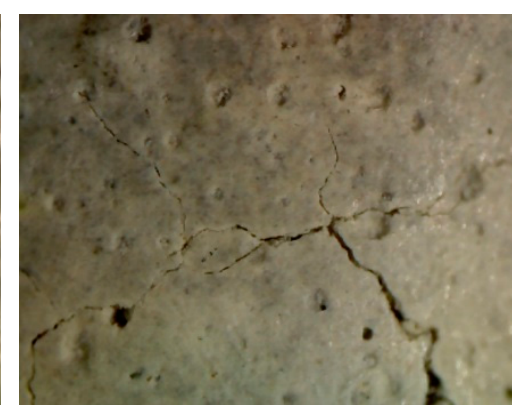

Map cracks and spalling

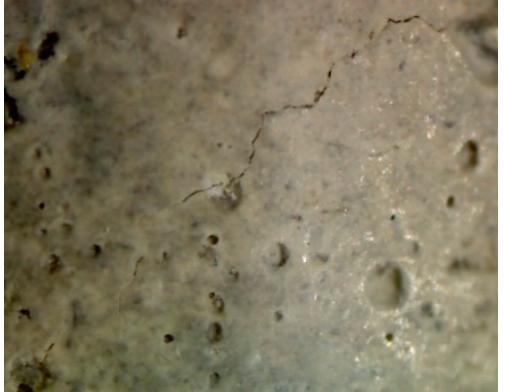

Diagonal crack

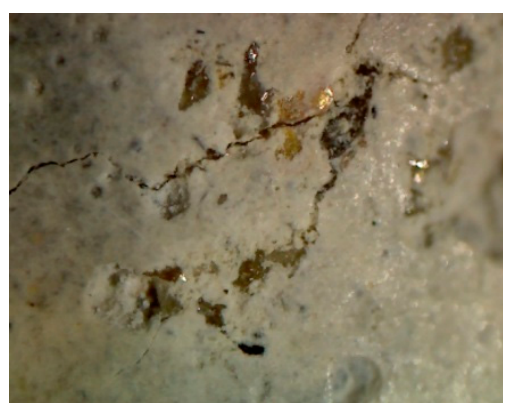

Surface scaling and transverse crack

Figure 11. A representative view of cracks formed on the surface of $12 \%$ slag-blended mortars observed under a light microscope after 84 days of immersion in $\mathrm{Na}_{2} \mathrm{SO}_{4}$ solution at $25^{\circ} \mathrm{C}$.

Table 3. Damage rating in nano- $\mathrm{TiO}_{2}$ containing $\mathrm{OPC}$ and slag-blended mortar specimens stored at 25 and $5{ }^{\circ} \mathrm{C}$ in $\mathrm{Na}_{2} \mathrm{SO}_{4}$ solution.

\begin{tabular}{|c|c|c|c|c|c|c|c|c|}
\hline \multirow{2}{*}{ Name } & \multicolumn{4}{|c|}{$25^{\circ} \mathrm{C}$} & \multicolumn{4}{|c|}{$5^{\circ} \mathrm{C}$} \\
\hline & 0 Day & 28 Days & 56 Days & 84 Days & 0 Day & 28 Days & 56 Days & 84 Days \\
\hline $0 \%$ OPC & 0 & 1 & 3 & 4 & 0 & 1 & 2 & 3 \\
\hline $3 \% \mathrm{OPC}$ & 0 & 1 & 3 & 4 & 0 & 1 & 2 & 4 \\
\hline $6 \% \mathrm{OPC}$ & 0 & 1 & 3 & 4 & 0 & 1 & 3 & 4 \\
\hline $9 \%$ OPC & 0 & 2 & 3 & 5 & 0 & 1 & 3 & 4 \\
\hline $12 \%$ OPC & 0 & 2 & 4 & 6 & 0 & 2 & 3 & 5 \\
\hline $0 \%$ slag-blended & 0 & 0 & 1 & 2 & 0 & 0 & 1 & 2 \\
\hline $3 \%$ slag-blended & 0 & 0 & 1 & 2 & 0 & 0 & 1 & 2 \\
\hline $6 \%$ slag-blended & 0 & 0 & 1 & 2 & 0 & 0 & 1 & 2 \\
\hline $9 \%$ slag-blended & 0 & 0 & 2 & 3 & 0 & 0 & 1 & 2 \\
\hline $12 \%$ slag-blended & 0 & 0 & 2 & 3 & 0 & 0 & 1 & 2 \\
\hline
\end{tabular}

0: No crack visible; 1: Slight cracks; 2: Some cracks; 3: Moderate cracks; 4: Severe cracks and some map cracks; 5: Severe cracks and moderate map cracks; 6: Severe cracks and minor spalling; 7: Intensive cracks and severe spalling.

\subsection{XRD, SEM, EDS, TGA and DSC Analyses}

Figures 12 and 13 show XRD graphs of the $0 \%$ and $12 \%$ OPC mortar and $0 \%$ and $12 \%$ slag-blended mortars stored in saturated limewater and $\mathrm{Na}_{2} \mathrm{SO}_{4}$ solution after 84 days of immersion at $25{ }^{\circ} \mathrm{C}$, respectively. Ettringite, portlandite, quartz, calcite, anatase $\left(\mathrm{TiO}_{2}\right)$, rutile, monosulfate and hydrated tetra calcium aluminate were observed in XRD graphs of $0 \%$ and $12 \%$ OPC and slag-blended mortars before immersion, as shown in Figure 12a,c and Figure 13a,c. Ettringite is a hydration product formed due to the reaction of gypsum present in cement clinker and forms when concrete is in a plastic state. Its formation provides dimensional stability to the mortar, as it compensates for chemical shrinkage. However, its formation in later stages in hardened concrete is detrimental [34]. The peaks of portlandite in the XRD pattern of slag-blended mortars (Figure 13a,c) were lower than OPC mortars (Figure 12a,c) due to the reaction of slag with portlandite, which consumed them during a pozzolanic reaction. XRD patterns of damaged OPC (Figure 12b,d) and slag-blended mortars (Figure 13b,d) showed new peaks 
of ettringite and gypsum after immersion in sulfate solution, existing peaks of ettringite were increased and portlandite peaks were decreased in intensity. The appearance of new peaks of ettringite and gypsum confirmed that expansion and cracking were due to the formation of ettringite and gypsum. Although slag-blended mortars had more $\mathrm{Al}_{2} \mathrm{O}_{3}$ content than OPC mortars but they showed resistance to sulfate attack than OPC mortars. In the case of hydration of slag, $\mathrm{Al}^{3+}$ is bound in calcium silicate gel as C-A-S-H which shelters it form attack of incoming sulfate ions [35]. Furthermore, less monosulfate is produced in slag mortars compared to OPC mortars [13]. Monosulfate serves as an important source of $\mathrm{Al}^{3+}$ ions for the formation of ettringite after attack of incoming sulfate ions [13]. Therefore, less ettringite is produced in slag blended mortars.

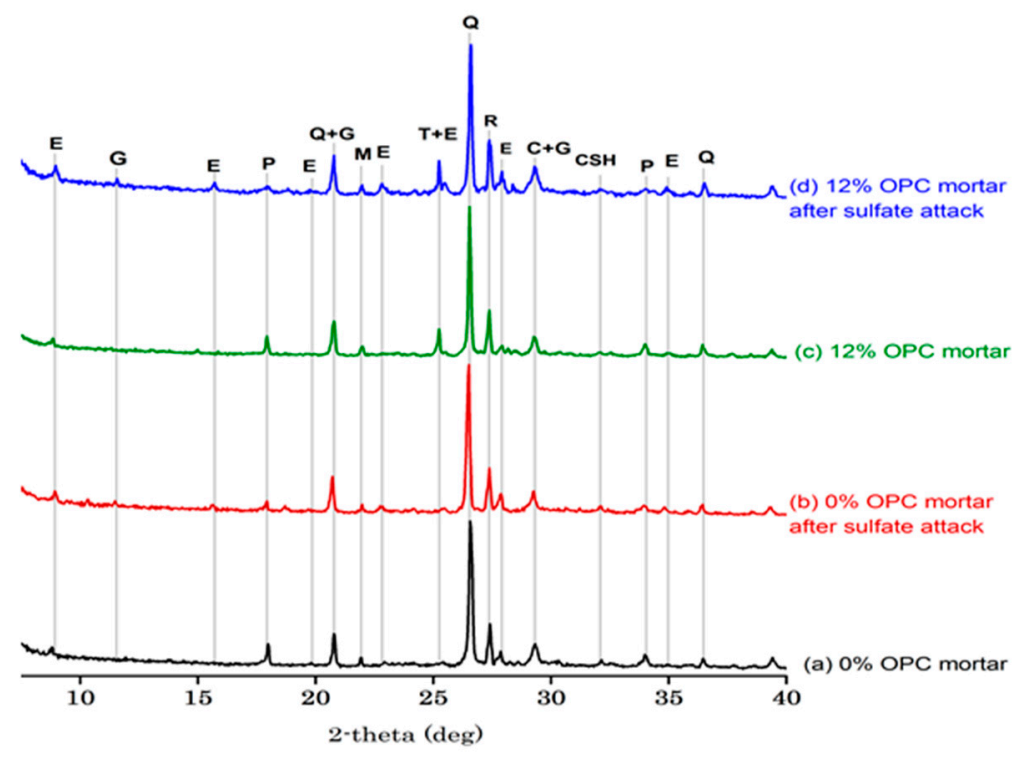

Figure 12. $\mathrm{XRD}$ pattern of $\mathrm{OPC}$ mortars $(\mathrm{E}=$ ettringite, $\mathrm{G}=$ gypsum, $\mathrm{P}=$ portlandite, $\mathrm{Q}=$ quartz, $\mathrm{M}=$ monosulfate, $\mathrm{T}=\mathrm{TiO}_{2}$ (anatase), $\mathrm{R}=$ rutile, $\mathrm{C}=$ calcite, $\mathrm{CSH}=$ calcium-silicate-hydrate).

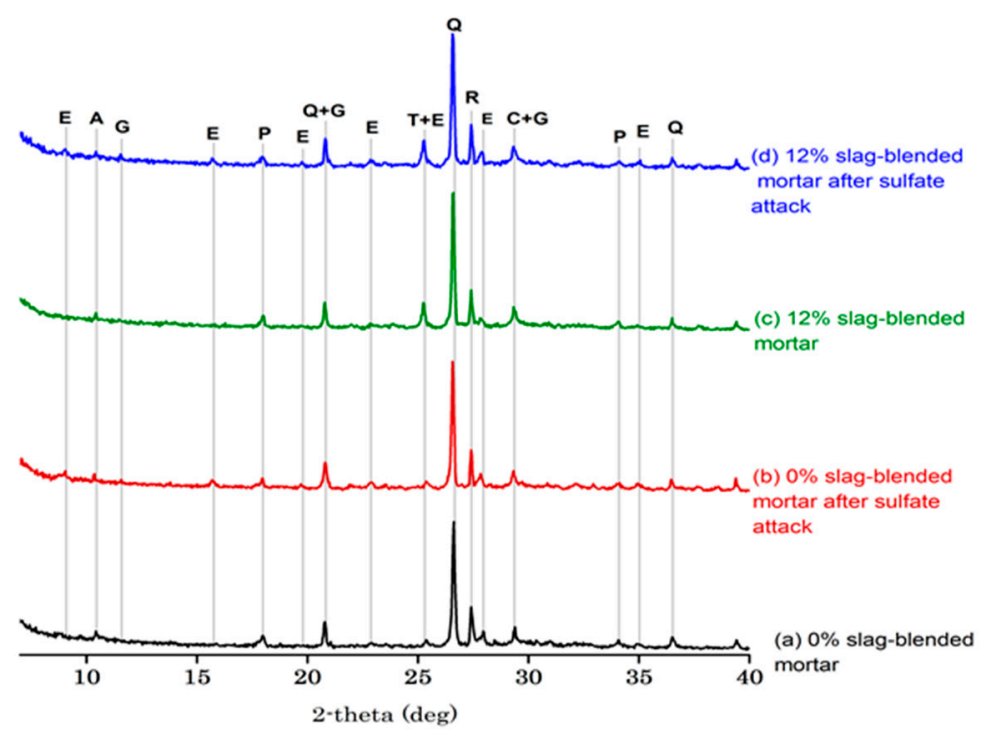

Figure 13. $\mathrm{XRD}$ pattern of slag-blended mortars $(\mathrm{E}=$ ettringite, $\mathrm{A}=$ tetra calcium aluminate hydrate, $\mathrm{G}=$ gypsum, $\mathrm{P}=$ portlandite, $\mathrm{Q}=$ quartz, $\mathrm{T}=\mathrm{TiO}_{2}$ (anatase), $\mathrm{R}=$ rutile, $\mathrm{C}=$ calcite, $\mathrm{CSH}=$ calciumsilicate-hydrate). 
SEM investigations were conducted at the low and high resolution on the deteriorated specimens to investigate the internal microstructure deterioration. In the SEM image shown in Figure 14, aggregate and cement paste can be seen. The gaps around aggregates are cracks and expansion in the interfacial transition zone between the aggregate and cement paste. The cracks around the aggregates suggest that a sulfate attack caused expansion in the interfacial transition zone and damaged the bond between the aggregate and the paste. Cracks around aggregates in the outer zone are more prominent than cracks around aggregates in the inner zone. This suggests that the deterioration in samples is concentric. As samples were cylindrical, the peripheral zone was attacked first; expansive forces were then generated near the surface, causing cracks around aggregates and in the cement paste. These microcracks permitted the penetration of more sulfate ions into the microstructure. As incoming sulfate ions reacted with interior hydration products and other susceptible compounds, new crystals of ettringite and gypsum were formed in the air voids and in the cracks. As a result, the peripheral zone exhibited greater deterioration than the core. The gaps were likely filled with ettringite and gypsum. Figures 15 and 16 show needle-like crystals of ettringite formed in the pores of cement paste and plate-like crystals of gypsum. EDS analysis conducted on the ettringite and gypsum crystals is also shown in the Figures 15 and 16. A crack around the gypsum crystals is given in Figure 16. This crack is likely formed because of the crystallization pressure of gypsum.

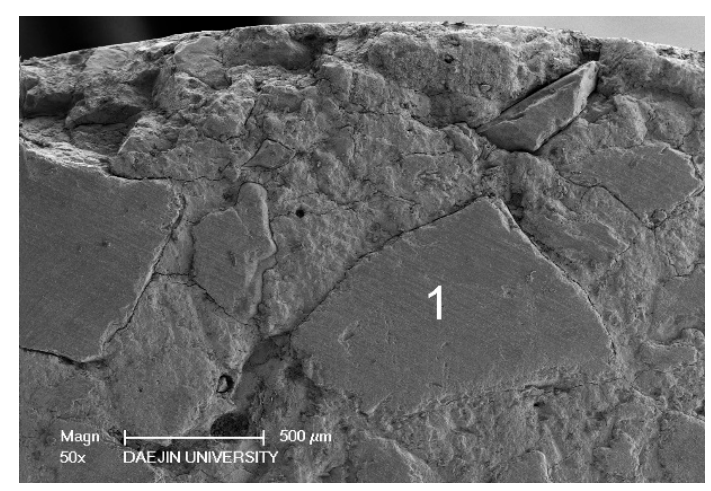

(a)

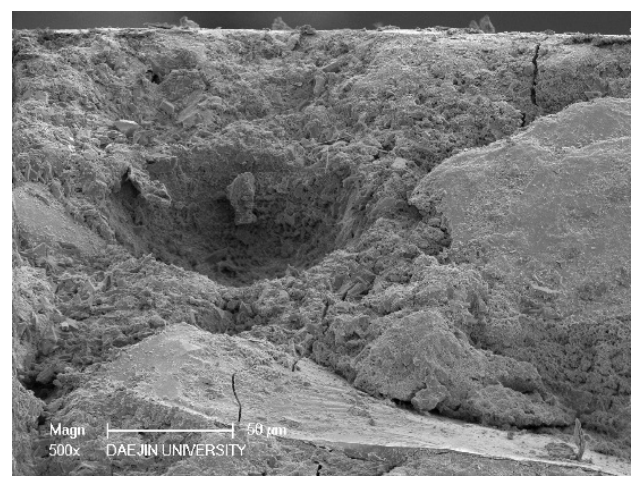

(b)

Figure 14. SEM images of $12 \%$ OPC mortar after sulfate attack (a) Cracks are more visible in the peripheral zone compared to the inner zone, visible crack on the outer side of aggregate 1 compared to its inner side. (b) A crack originating from the outer surface moving toward the inner core.
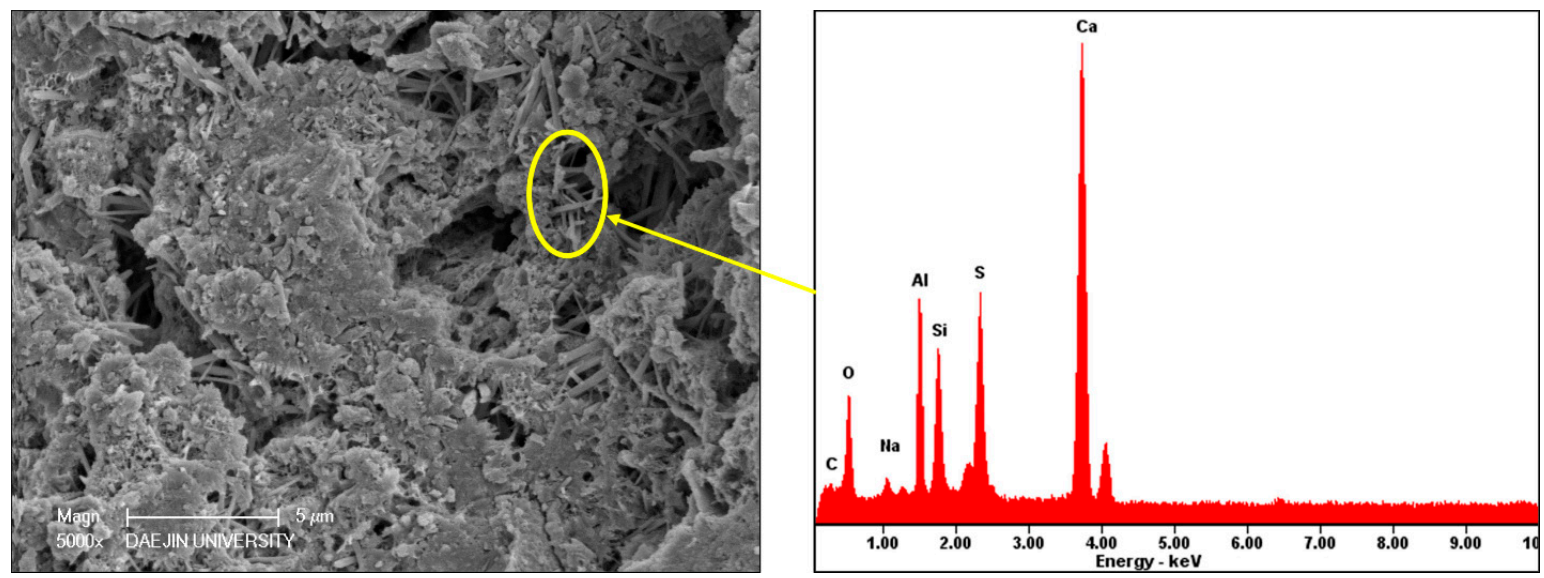

Figure 15. SEM image and EDS analyses of ettringite crystals formed in pores of $12 \%$ OPC mortar immersed at $25{ }^{\circ} \mathrm{C}$ in $10 \% \mathrm{Na}_{2} \mathrm{SO}_{4}$ solution. 

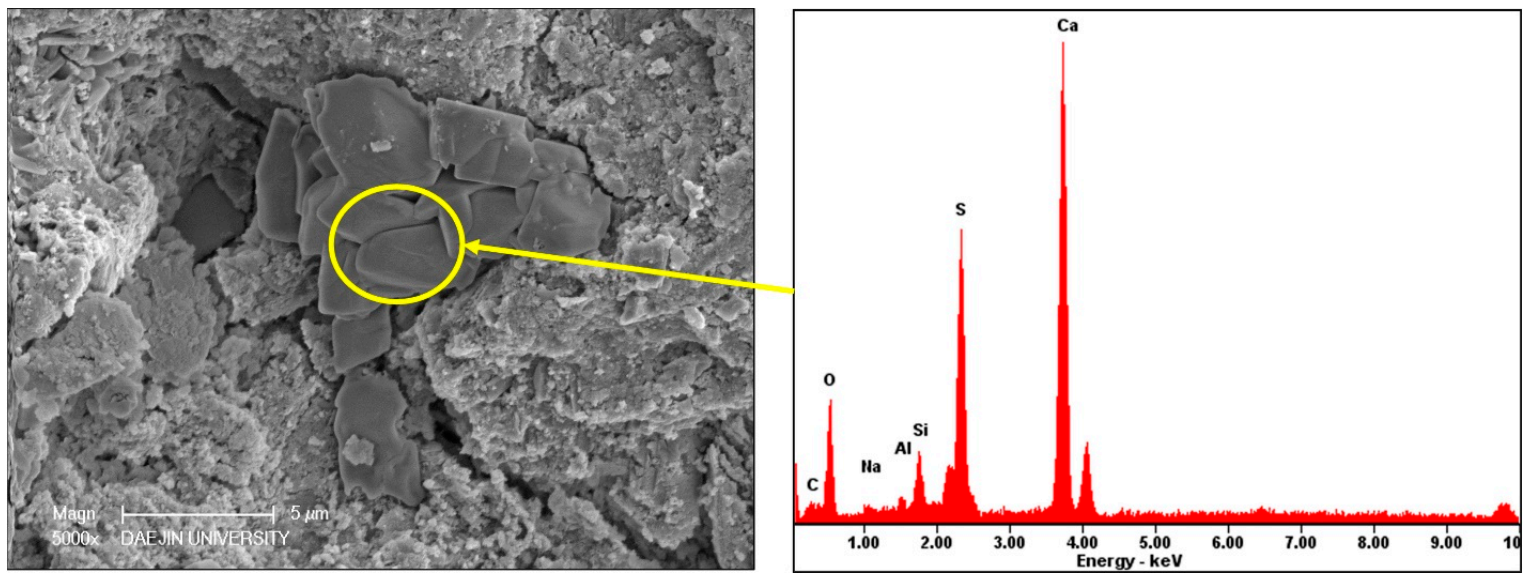

Figure 16. SEM image and EDS analyses of gypsum in $12 \%$ OPC mortar immersed at $25{ }^{\circ} \mathrm{C}$ in $10 \%$ $\mathrm{Na}_{2} \mathrm{SO}_{4}$ solution.

Thermogravimetric analysis (TGA) and differential scanning calorimetry (DSC) analysis were conducted on $0 \%, 6 \%, 12 \%$ OPC and slag blended mortars stored in saturated limewater and sodium sulfate solution at $25{ }^{\circ} \mathrm{C}$. Differential thermogravimetry (DTG) and differential scanning calorimetry (DSC) curves for $12 \%$ OPC mortars stored in saturated limewater and $\mathrm{Na}_{2} \mathrm{SO}_{4}$ solution at $25^{\circ} \mathrm{C}$ for 84 days is shown in Figure 17.

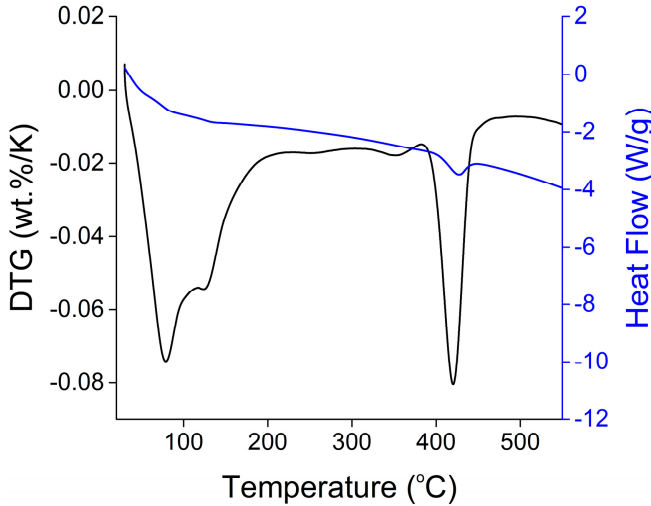

(a)

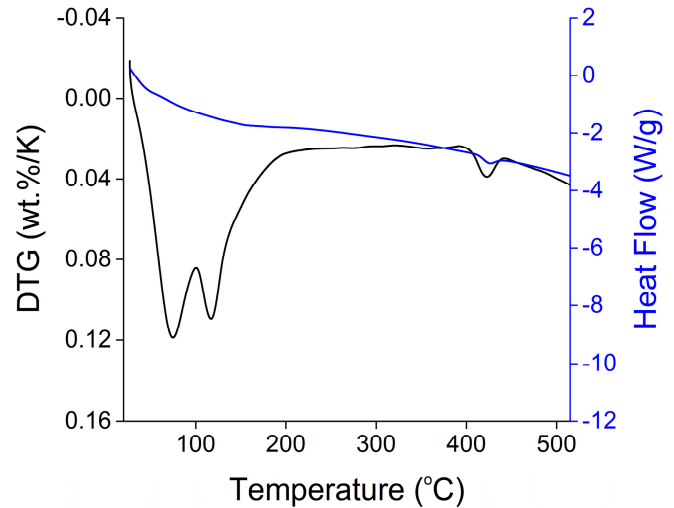

(b)

Figure 17. DTG and DSC curves in $12 \%$ OPC mortars stored in (a) saturated limewater; (b) $10 \%$ $\mathrm{Na}_{2} \mathrm{SO}_{4}$ solution.

In Figure 17a, DTG curve shows two large peak peaks at $80^{\circ} \mathrm{C}$ and $430{ }^{\circ} \mathrm{C}$, these decompositions peaks are due to the dehydration of ettringite and portlandite respectively [28]. But after exposure to sulfate attack, the peak corresponding to the portlandite has been significantly reduced, a new peak has emerged at about $130{ }^{\circ} \mathrm{C}$. This new peak is due to the decomposition of gypsum which was produced during sulfate attack. These new peaks can also be observed in XRD shown in Figure 12d. Figure 18 shows the percentage of portlandite in mortars stored in saturated limewater (controlled mortars) and $\mathrm{Na}_{2} \mathrm{SO}_{4}$ solution (damaged mortars) [28]. This figure shows that after sulfate attack, reduction in $\mathrm{CH}$ content is proportional to the increasing amount of nano- $\mathrm{TiO}_{2}$. Enthalpy of ettringite and gypsum corresponding to temperature $80-150{ }^{\circ} \mathrm{C}$ and portlandite corresponding to $400-500{ }^{\circ} \mathrm{C}$ was calculated from DSC curves [36] and is shown in Figure 19. A decreasing trend in enthalpy of $\mathrm{CH}$ in mortar samples after exposure to sulfate solution can be observed with the addition of nano- $\mathrm{TiO}_{2}$. Enthalpy of ettringite and gypsum are shown in Figure 19b. Contrary to $\mathrm{CH}$ enthalpy, here an increase in enthalpy can be observed with the addition of nano- $\mathrm{TiO}_{2}$ after sulfate attack. 


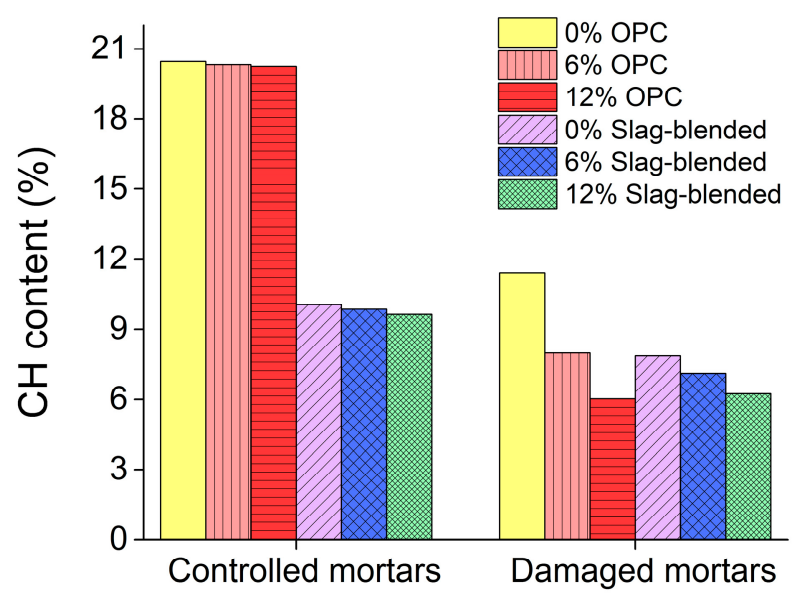

Figure 18. Portlandite content (\%) in mortars stored in controlled and aggressive conditions.

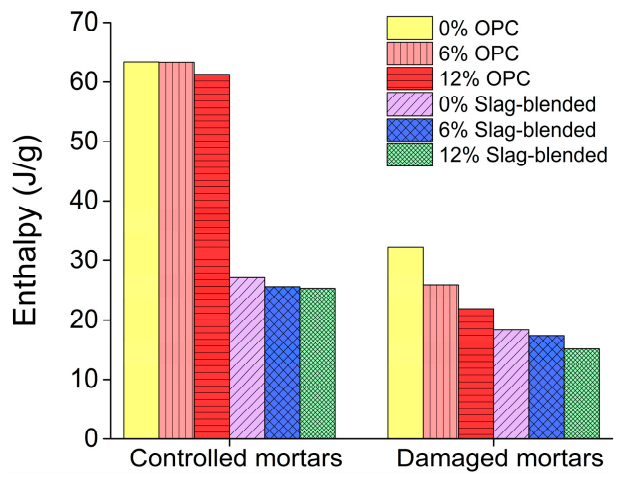

(a)

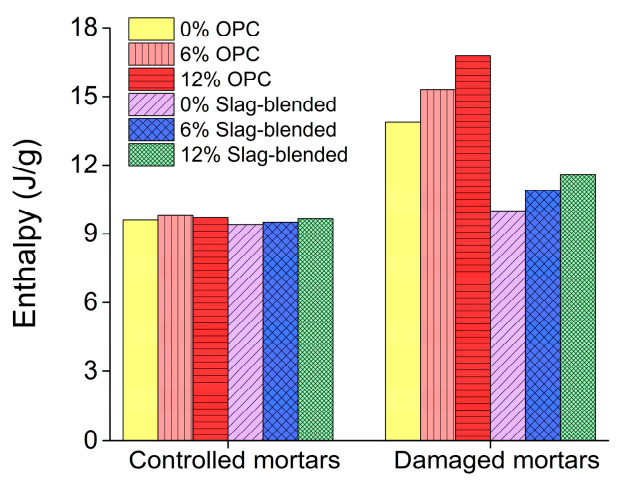

(b)

Figure 19. DSC results for (a) portlandite peaks at about $440{ }^{\circ} \mathrm{C} ;(\mathbf{b})$ ettringite and gypsum peaks at $90-140{ }^{\circ} \mathrm{C}$.

Crystallization pressure is considered to be responsible for the mechanism of expansion in sulfate attack [9]. When ettringite or gypsum crystals grow in a confined space, they exert an expansive force on the walls of the pores. According to Scherer [37], crystallization pressure is inversely proportional to the size of the pores. If the pores in which crystals grow are smaller in size, then the crystallization pressure will be higher. When the crystallization pressure is greater than the tensile strength of the mortar, the pores will expand and microcracks will occur. After microcracking, more sulfate ions will enter the sample, reacting with portlandite and forming gypsum.

$\mathrm{TiO}_{2}$ is an inert material [14,38], it does not react with water, cement and incoming sulfate ions. The nano- $\mathrm{TiO}_{2}$ particles act as nuclei for hydration reaction. The hydration products grow around them and fill the voids, thus reduce the porosity [14]. Mercury intrusion porosimetry (MIP) studies of nano- $\mathrm{TiO}_{2}$ containing cementitious materials $[14,39-42]$ have shown that the addition of nano- $\mathrm{TiO}_{2}$ have refined their pores and the most probable pore diameters of cementitious materials have shifted towards smaller pore diameters. As stated above that during sulfate attack, expansive products (ettringite and gypsum) are created in the pores of the cement mortar and they create crystallization pressure on the walls of pores. If the size of pores is smaller, the crystallization pressure will be higher and vice versa. Here, the pore sizes were reduced due to the addition of nano- $-\mathrm{TiO}_{2}$, so the crystallization pressure was higher due to the formation of ettringite and gypsum crystals in pores of nano- $\mathrm{TiO}_{2}$ containing mortars than control mortars. Secondly, the addition of nano- $\mathrm{TiO}_{2}$ particles can reduce the tensile strength of mortar [15]; therefore, the addition of nano- $\mathrm{TiO}_{2}$ not only increased crystallization pressure, which is a tensile force but also simultaneously reduced tensile strength, 
leaving mortars with nano- $\mathrm{TiO}_{2}$ more vulnerable to sulfate attack and salt crystallization pressure than normal mortars. According to Santhanam et al. [43], the presence of voids can reduce expansive stresses due to crystallization, which can reduce the number of cracks in the paste. The researchers [43] observed a slower rate of disintegration in the air-entrained mortars than in the non-air-entrained mortars. Therefore, nano- $\mathrm{TiO}_{2}$ containing mortars had less voids and more expansive stresses created due to crystallization pressure in smaller size voids and were ultimately more damaged than mortars without nano- $\mathrm{TiO}_{2}$. Lee and Kurtis [44] also concluded that the addition of nanoparticles increases the salt crystallization pressure. In their study, mortars containing nanoparticles showed greater damage due to salt crystallization than mortars without nanoparticles. $\mathrm{TiO}_{2}$ containing slag-blended mortars were resistant to sulfate attack because slag reacts with portlandite to form calcium silicate hydrate [31]. It consumes portlandite and increases the amount of CSH in mortars. Additional hydrates are formed in larger capillary pores and reduce pore connectivity [45]. This process likely reduced the porosity and permeability of $\mathrm{TiO}_{2}$ containing slag-blended mortars and increased the compressive and tensile strength of mortars [6]. The lower content of portlandite in slag-blended mortars can be observed in the XRD pattern shown in Figure 13. The other reactive hydration products susceptible to sulfate attack are monosulfoaluminate hydrate, calcium aluminate hydrate and calcium aluminate hydroxide. These products were likely in lower quantities in slag mortars due to the absence of $C_{3} A$ clinker phases in slag and these products are less reactive when present in slag [36]. As these phases are required for the formation of ettringite, their lower quantities in slag are not sufficient to cause ettringite-related expansion and cracking. The higher tensile strength of slag mortars (compared to OPC mortars) can also resist the expansion due to the formation of ettringite so nano- $\mathrm{TiO}_{2}$ containing slag-blended mortars were more resistant to sulfate attack than so nano- $\mathrm{TiO}_{2}$ containing OPC mortars.

\section{Conclusions}

In this study, we investigated the influence of titanium dioxide $\left(\mathrm{TiO}_{2}\right)$ nanoparticles on the sulfate attack upon ordinary Portland cement and slag-blended mortars. $\mathrm{Nano}^{-\mathrm{TiO}_{2}}$ containing mortars were immersed in $10 \% \mathrm{Na}_{2} \mathrm{SO}_{4}$ solution at 25 and $5{ }^{\circ} \mathrm{C}$. The expansion, variation in mass and surface microhardness were observed. Deteriorated samples were analyzed using XRD, SEM, EDS, TGA and DSC tests. Based on the test results, the following points were concluded.

Deterioration due to sulfate attack occurred on all $\mathrm{TiO}_{2}$ containing mortars. The results show that the addition of $\mathrm{TiO}_{2}$ has robust effects on the rate of sulfate attack on OPC and slag-blended mortars. The extent of damage increases with the addition of $\mathrm{TiO}_{2}$ nanoparticles. It is recommended that mortars and concrete structures containing $\mathrm{TiO}_{2}$ for self-cleaning and air purifying purposes should be designed as sulfate resistant.

The $\mathrm{TiO}_{2}$ containing slag-blended mortars showed lower expansion, mass and surface hardness changes and cracking. So, blast furnace slag can be used to reduce sulfate attack in nano- $\mathrm{TiO}_{2}$ containing mortars.

The $\mathrm{TiO}_{2}$ containing mortar and concrete structures exposed to higher temperatures are more vulnerable to sulfate attack as the rate of expansion, mass variation and cracks were higher in mortars stored at $25^{\circ} \mathrm{C}$ temperature than at $5{ }^{\circ} \mathrm{C}$. Specimens at lower temperatures take more time to match the expansion of specimens at higher temperatures.

The rate and severity of sulfate attack on $\mathrm{TiO}_{2}$ containing cementitious materials should be investigated by varying the factors like the type of cations of sulfate solution $\left(\mathrm{K}^{+}, \mathrm{Mg}^{2+}, \mathrm{Ca}^{2+}\right), \mathrm{pH}$ of the solution and size of the specimens. Also, the influence of titanium dioxide on sulfate attack upon other materials such as geopolymer concrete should be investigated.

Acknowledgments: This study was supported by the Technology Development Program (C0532231) funded by the Ministry of SMEs and Startups (MMS, Korea).

Author Contributions: Atta-ur-Rehman, Abdul Qudoos, and Hong Gi Kim conceived, designed, performed the experiments and analyzed the data under the guidance and supervision of Jae-Suk Ryou.

Conflicts of Interest: The authors have no conflict of interest. 


\section{References}

1. Chen, J.; Poon, C.-S. Photocatalytic construction and building materials: From fundamentals to applications. Build. Environ. 2009, 44, 1899-1906. [CrossRef]

2. Chen, J.; Kou, S.-C.; Poon, C.-S. Photocatalytic cement-based materials: Comparison of nitrogen oxides and toluene removal potentials and evaluation of self-cleaning performance. Build. Environ. 2011, 46, 1827-1833. [CrossRef]

3. Strini, A.; Roviello, G.; Ricciotti, L.; Ferone, C.; Messina, F.; Schiavi, L.; Corsaro, D.; Cioffi, R. TiO ${ }_{2}$-based photocatalytic geopolymers for nitric oxide degradation. Materials 2016, 9, 513. [CrossRef] [PubMed]

4. Ohama, Y.; Van Gemert, D. Application of Titanium Dioxide Photocatalysis to Construction Materials: State-of-the-Art Report of the Rilem Technical Committee 194-TDP; Springer Science \& Business Media: New York, NY, USA, 2011; Volume 5.

5. Hüsken, G.; Hunger, M.; Brouwers, H. Experimental study of photocatalytic concrete products for air purification. Build. Environ. 2009, 44, 2463-2474. [CrossRef]

6. Siddique, R.; Khan, M.I. Supplementary Cementing Materials; Springer Science \& Business Media: New York, NY, USA, 2011.

7. Virgalitte, S.J.; Luther, M.D.; Rose, J.H.; Mather, B.; Bell, L.W.; Ehmke, B.A.; Klieger, P.; Roy, D.M.; Call, B.M.; Hooton, R.D. Ground Granulated Blast-Furnace Slag as a Cementitious Constituent in Concrete; ACI Report 233R-95; American Concrete Institute: Detroit, MI, USA, 1995.

8. Bastos, G.; Patiño-Barbeito, F.; Patiño-Cambeiro, F.; Armesto, J. Nano-inclusions applied in cement-matrix composites: A review. Materials 2016, 9, 1015. [CrossRef] [PubMed]

9. Yu, C.; Sun, W.; Scrivener, K. Mechanism of expansion of mortars immersed in sodium sulfate solutions. Cem. Concr. Res. 2013, 43, 105-111. [CrossRef]

10. Gruyaert, E.; Van den Heede, P.; Maes, M.; De Belie, N. Investigation of the influence of blast-furnace slag on the resistance of concrete against organic acid or sulphate attack by means of accelerated degradation tests. Cem. Concr. Res. 2012, 42, 173-185. [CrossRef]

11. Santhanam, M.; Cohen, M.D.; Olek, J. Sulfate attack research-Whither now? Cem. Concr. Res. 2001, 31, 845-851. [CrossRef]

12. Neville, A. The confused world of sulfate attack on concrete. Cem. Concr. Res. 2004, 34, 1275-1296. [CrossRef]

13. Marchand, J.; Odler, I.; Skalny, J.P. Sulfate Attack on Concrete; CRC Press: New York, NY, USA, 2003.

14. Chen, J.; Kou, S.-C.; Poon, C.-S. Hydration and properties of nano- $\mathrm{TiO}_{2}$ blended cement composites. Cem. Concr. Compos. 2012, 34, 642-649. [CrossRef]

15. Lucas, S.; Ferreira, V.; de Aguiar, J.B. Incorporation of titanium dioxide nanoparticles in mortars-Influence of microstructure in the hardened state properties and photocatalytic activity. Cem. Concr. Res. 2013, 43, 112-120. [CrossRef]

16. Meng, T.; Yu, Y.; Qian, X.; Zhan, S.; Qian, K. Effect of nano- $\mathrm{TiO}_{2}$ on the mechanical properties of cement mortar. Constr. Buil. Mater. 2012, 29, 241-245. [CrossRef]

17. Lee, B.Y. Effect of Titanium Dioxide Nanoparticles on Early Age and Long Term Properties of Cementitious Materials; Georgia Institute of Technology: Atlanta, Georgia, 2012.

18. Pérez-Nicolás, M.; Balbuena, J.; Cruz-Yusta, M.; Sánchez, L.; Navarro-Blasco, I.; Fernández, J.M.; Alvarez, J.I. Photocatalytic $\mathrm{NO}_{X}$ abatement by calcium aluminate cements modified with $\mathrm{TiO}_{2}$ : Improved $\mathrm{NO}_{2}$ conversion. Cem. Concr. Res. 2015, 70, 67-76. [CrossRef]

19. Standard Test Method for Length Change of Hydraulic-Cement Mortars Exposed to a Sulfate Solution American; ASTM C1012/C1012M-18a; American Society for Testing and Materials: West Conshohocken, PA, USA, 2018.

20. Van Tittelboom, K.; De Belie, N.; Hooton, R.D. Test methods for resistance of concrete to sulfate attack-A critical review. In Performance of Cement-Based Materials in Aggressive Aqueous Environments; Springer: New York, NY, USA, 2013; pp. 251-288.

21. Ferraris, C.; Stutzman, P.; Peltz, M.; Winpigler, J. Developing a more rapid test to assess sulfate resistance of hydraulic cements. J. Res. Natl. Inst. Stand. Technol. 2005, 110, 529. [CrossRef] [PubMed]

22. Ferraris, C.F.; Clifton, J.R.; Stutzman, P.E.; Garboczi, E. Mechanisms of Chemical Degradation of Cement-Based Systems; CRC Press: New York, NY, USA, 1997; p. 185. 
23. Standard Test Method for Compressive Strength of Hydraulic Cement Mortars (Using 2-in. or [50-mm] Cube Specimens); ASTM C109/C109M-16a; American Society for Testing and Materials: West Conshohocken, PA, USA, 2016.

24. Standard Test Method for Flexural Strength and Modulus of Hydraulic Cement Mortars; ASTM, C348-02; American Society for Testing and Materials: West Conshohocken, PA, USA, 2002.

25. Standard Test Method for Density, Absorption and Voids in Hardened Concrete; ASTM, C642-13; American Society for Testing and Materials: West Conshohocken, PA, USA, 2013.

26. Igarashi, S.; Bentur, A.; Mindess, S. Microhardness testing of cementitious materials. Adv. Cem. Based Mater. 1996, 4, 48-57. [CrossRef]

27. Sarkar, S.L.; Aimin, X.; Jana, D. Scanning electron microscopy, X-ray microanalysis of concretes-7. In Handbook of Adhesives Raw Materials; Noyes Publications: Park Ridge, NJ, USA, 2001.

28. Lothenbach, B.; Durdzinski, P.; De Weerdt, K. Thermogravimetric analysis. In A Practical Guide to Microstructural Analysis of Cementitious Materials; CRC Press: Oxford, UK, 2016; pp. 177-212.

29. Nazari, A.; Riahi, S. The effect of $\mathrm{TiO}_{2}$ nanoparticles on water permeability and thermal and mechanical properties of high strength self-compacting concrete. Mater. Sci. Eng. A 2010, 528, 756-763. [CrossRef]

30. Hooton, R.D. Canadian use of ground granulated blast-furnace slag as a supplementary cementing material for enhanced performance of concrete. Can. J. Civ. Eng. 2000, 27, 754-760. [CrossRef]

31. Mehta, P.K. Concrete: Structure, Properties and Materials; Prentice Hall: Upper Saddle River, NJ, USA, 1986.

32. Bouikni, A.; Swamy, R.N.; Bali, A. Durability properties of concrete containing $50 \%$ and $65 \%$ slag. Constr. Build. Mater. 2009, 23, 2836-2845. [CrossRef]

33. Lang, E. Blast furnace cements. In Structure and Performance of Cements, 2nd ed.; Bensted, J., Barnes, P., Eds.; Spon Press: London, UK, 2002; pp. 310-325.

34. Menéndez, E.; Matschei, T.; Glasser, F.P. Sulfate attack of concrete. In Performance of Cement-Based Materials in Aggressive Aqueous Environments; Springer: New York, NY, USA, 2013; pp. 7-74.

35. Whittaker, M.; Zajac, M.; Ben Haha, M.; Black, L. The impact of alumina availability on sulfate resistance of slag composite cements. Constr. Build. Mater. 2016, 119, 356-369. [CrossRef]

36. Bassuoni, M.T.; Nehdi, M.L. Durability of self-consolidating concrete to sulfate attack under combined cyclic environments and flexural loading. Cem. Concr. Res. 2009, 39, 206-226. [CrossRef]

37. Scherer, G.W. Crystallization in pores. Cem. Concr. Res. 1999, 29, 1347-1358. [CrossRef]

38. Jayapalan, A.; Lee, B.; Fredrich, S.; Kurtis, K. Influence of additions of anatase $\mathrm{TiO}_{2}$ nanoparticles on early-age properties of cement-based materials. Transp. Res. Rec. J. Transp. Res. Board 2010, 2141, 41-46. [CrossRef]

39. Yang, L.Y.; Jia, Z.J.; Zhang, Y.M.; Dai, J.G. Effects of nano- $\mathrm{TiO}_{2}$ on strength, shrinkage and microstructure of alkali activated slag pastes. Cem. Concr. Compos. 2015, 57,1-7. [CrossRef]

40. Zhang, R.; Cheng, X.; Hou, P.; Ye, Z. Influences of nano- $\mathrm{TiO}_{2}$ on the properties of cement-based materials: Hydration and drying shrinkage. Constr. Build. Mater. 2015, 81, 35-41. [CrossRef]

41. Jimenez-Relinque, E.; Rodriguez-Garcia, J.R.; Castillo, A.; Castellote, M. Characteristics and efficiency of photocatalytic cementitious materials: Type of binder, roughness and microstructure. Cem. Concr. Res. 2015, 71, 124-131. [CrossRef]

42. Nazari, A.; Riahi, $\mathrm{S}$. $\mathrm{TiO}_{2}$ nanoparticles effects on physical, thermal and mechanical properties of self compacting concrete with ground granulated blast furnace slag as binder. Energy Build. 2011, 43, 995-1002. [CrossRef]

43. Santhanam, M.; Cohen, M.D.; Olek, J. Mechanism of sulfate attack: A fresh look: Part 2. Proposed mechanisms. Cem. Concr. Res. 2003, 33, 341-346. [CrossRef]

44. Lee, B.Y.; Kurtis, K.E. Effect of pore structure on salt crystallization damage of cement-based materials: Consideration of $\mathrm{w} / \mathrm{b}$ and nanoparticle use. Cem. Concr. Res. 2017, 98, 61-70. [CrossRef]

45. Divsholi, B.S.; Lim, T.Y.D.; Teng, S. Durability properties and microstructure of ground granulated blast furnace slag cement concrete. Int. Concr. Struct. Mater. 2014, 8, 157-164. [CrossRef]

(C) 2018 by the authors. Licensee MDPI, Basel, Switzerland. This article is an open access article distributed under the terms and conditions of the Creative Commons Attribution (CC BY) license (http:/ / creativecommons.org/licenses/by/4.0/). 